\title{
Labetuzumab-SN-38 Immunoconjugate IMMU-130
}

National Cancer Institute

\section{Source}

National Cancer Institute. Labetuzumab-SN-38 Immunoconjugate IMMU-130. NCI

Thesaurus. Code C95710.

An antibody-drug conjug ate (ADC) containing labetuzumab, a mildly reduced, anti-

CEACAM5 humanized monoclonal antibody, conjug ated to the potent topoisomerase I inhibitor SN-38, with antineoplastic activity. The monoclonal antibody moiety of antibodydrug conjug ate IMMU-130 selectively binds to carcinoembryonic cell adhesion molecule 5 (CEACAM5), which is abundantly expressed on the surface of a majority of solid tumors. Upon internalization and proteolytic cleavage, SN-38, the active metabolite of irinotecan, inhibits the activity of topoisomerase I in the tumor cells, eventually inhibiting both DNA replication and transcription and leading to tumor cell apoptosis. 